Irshad M. Sulaiman · Ron Fayer · Chunfu Yang

Monica Santin · Olga Matos · Lihua Xiao

\title{
Molecular characterization of Enterocytozoon bieneusi in cattle indicates that only some isolates have zoonotic potential
}

Published online: 30 March 2004

(C) Springer-Verlag 2004

\section{Parasitol Res (2004) Dol 10.1007/s00436-003-1049-5}

PCR amplification of the IST section: The paragraph should read:

A nested PCR protocol was used to amplify the ITS region of the rRNA gene of E. bieneusi isolates (22). For primary PCR, a PCR product of $410 \mathrm{bp}$ was amplified using primers AL4037 [5'-GATGGTCATAGGGATGAAGAGCTT-3'] and AL4039 [5'-ACGGATCCAAGTGATCCTGTATT-3']. The PCR reaction consisted of $1.0 \mu \mathrm{l}$ of DNA, $200 \mu \mathrm{M}$ each of dNTP, $1 \times \mathrm{PCR}$ buffer (Perkin Elmer, Foster City, Calif.), $3.0 \mathrm{mM} \mathrm{MgCl} 2,5.0 \mathrm{U}$ of Taq polymerase (GIBCO BRL, Frederick, Md.), and
$200 \mathrm{nM}$ of each primer in a total of $100 \mu \mathrm{l}$ reaction medium. The reactions were carried out for 35 cycles $\left(94^{\circ} \mathrm{C}\right.$ for $45 \mathrm{~s}, 55^{\circ} \mathrm{C}$ for $45 \mathrm{~s}$, and $72^{\circ} \mathrm{C}$ for $60 \mathrm{~s}$ ) in a Perkin Elmer GeneAmp PCR 9700 thermocycler, with an initial hot start $\left(94^{\circ} \mathrm{C}\right.$ for $\left.5 \mathrm{~min}\right)$ and a final extension $\left(72^{\circ} \mathrm{C}\right.$ for $10 \mathrm{~min}$ ). For secondary PCR, a fragment of $392 \mathrm{bp}$ was amplified from $2.5 \mu \mathrm{l}$ of primary PCR reaction, using primers AL4038 [5'-AGGGATGAAGAGCTTCGGCTCTG-3'] and AL4040 [5'-AGTGATCCTGTATTAGGGATATT-3']. The conditions for the secondary PCR were identical to the primary PCR. The PCR products were analyzed by agarose gel electrophoresis and visualized after ethidium bromide staining.

The online version of the original article can be found at http:// dx.doi.org/10.1007/s00436-003-1049-5

I. M. Sulaiman · L. Xiao $(\bowtie)$

Division of Parasitic Diseases, Centers for Disease Control

and Prevention, Atlanta, GA 30341, USA

E-mail: 1xiao@cdc.gov

Tel.: + 1-770-4884840

Fax: + 1-770-4884454

R. Fayer

Animal and Natural Resources Institute,

Agriculture Research Service, Environmental Microbial Safety

Laboratory, United States Department of Agriculture,

Beltsville, MD 20705, USA

C. Yang

Division of AIDS, STD and TB Laboratory Research,

Centers for Disease Control and Prevention,

Atlanta, GA 30333, USA

O. Matos

Unidade de Protozoarios Oportunistas/VIH e Outras Protozooses, Unidade de Parasitologia e Microbiologia Medicas (UPMM),

Instituto de Higiene e Medicina Tropical, Universidade Nova de Lisboa, Lisbon, Portugal 